\title{
O PAPEL DO AMICUS CURIAE E DAS AUDIENCIAS PÚBLICAS COMO INSTRUMENTOS DE APERFEIÇOAMENTO E LEGITIMIDADE DAS DECISÕES DO SUPREMO TRIBUNAL FEDERAL
}

\author{
Luciana de Toledo Temer Lulia ${ }^{1}$ \\ Diego Sígoli Domingues ${ }^{2}$
}

\section{Resumo}

O presente artigo se propõe a compreender a importância da atuação do amicus curiae e da realização das audiências públicas como instrumentos de aperfeiçoamento das decisões judiciais, bem como de legitimidade do Poder Judiciário, sobretudo do Supremo Tribunal Federal. Por um lado, o amicus curiae atua como sendo um terceiro autônomo e sem interesse direto na lide, ao qual não compõe nenhum dos polos da relação processual posta em juízo, mas auxilia os julgadores nas questões eminentemente técnicas e jurídicas, principalmente aquelas dotadas com conteúdo de direitos difusos e coletivos, visando à correta aplicação do direito ao caso, propiciando eficiência da atividade jurisdicional. De outro lado, a realização de audiências públicas amplia o debate sobre o tema posto sub judice, eis que assegura maior participação de determinada parcela da sociedade envolvida ou efetiva e potencialmente atingida pela decisão a ser proferida, assegurando a democratização quanto à pluralização do debate constitucional, o acesso à justiça de modo amplo, bem como auxilia na legitimação das decisões do Supremo Tribunal Federal sobre temas relevantes.

Palavras-chave: Amicus Curiae. Audiências públicas. Aperfeiçoamento das decisões judiciais do Supremo Tribunal Federal. Instrumentos de legitimação e democratização.

\footnotetext{
${ }^{1}$ Doutora em Direito pela Pontifícia Universidade Católica de São Paulo PUC/SP. Professora do Programa de Mestrado em Direito da Universidade Nove de Julho. Professora da Graduação e pós-graduação latu sensu da Faculdade de Direito da Pontifícia Universidade Católica. E-mail: lutemer@uol.com.br

${ }^{2}$ Mestrando em Direito pela Universidade Nove de Julho. E-mail: diego_sigoli@hotmail.com
} 


\section{INTRODUÇÃO}

O ser humano é o centro da ordem jurídica, debruçando-se a ciência jurídica na criação e manutenção de mecanismos para possibilitar a convivência harmônica das pessoas e, de um modo geral, a pacificação social.

Bem por isso, a utilização de instrumentos democráticos de participação popular vem crescendo exponencialmente ao longo dos últimos anos, principalmente em questões de grande e notória repercussão social, sendo que a intervenção da sociedade civil através de tais figuras jurídicas, de uma só vez aperfeiçoam, democratizam e legitimam as decisões tomadas pelos entes e poderes públicos de um modo geral.

Tais instrumentos são essenciais para o Estado Democrático de Direito, possibilitando a participação de diversos atores da sociedade no enfrentamento de problemas, sejam eles concretos ou iminentes, e tomada de decisões, perante os poderes Legislativo, Executivo e Judiciário, com vistas a assegurar e legitimar a democracia representativa.

Na esfera do Poder Legislativo, a qual as audiências públicas são utilizadas a longa data, este instrumento democrático a um só tempo é capaz de endossar a legitimidade dos parlamentares, seja na discussão acerca de determinado projeto de lei, como por exemplo, podemos citar o Plano Diretor de determinado Município, seja no acompanhamento do controle fiscal, contábil, orçamentário e patrimonial das contas do Poder Executivo.

Há, inclusive, previsão constitucional para a convocação por parte do Congresso Nacional de entidades da sociedade civil para a realização de audiências de públicas, sempre que necessário, para a discussão acerca de questões que estão na pauta das comissões, conforme reza o artigo 58, $\$ 2^{\circ}$, inciso II, da Carta Magna.

A seu turno, o Poder Executivo também promove a inclusão representativa democrática quando convoca audiências públicas para discussões sensíveis e extremamente importantes que afetam grande parte da população adstrita a sua competência, como por exemplo, a elaboração do Plano Plurianual e questões orçamentárias, metas de governo, dando voz a quem de direito, ou seja, aos diversos atores da sociedade.

Logo, embora os membros do Legislativo e Executivo tenham sido escolhidos democraticamente, através de voto direto, os mandatos a eles conferidos pelos eleitores embora legitimem suas ações, absolutamente não afastam e tampouco esgotam o direito de participação democrática da população, exercida por inúmeros instrumentos jurídicos.

Por outro lado, diversamente do que ocorre com os membros do Legislativo e Executivo, eleitos democraticamente em todas as suas unidades, os magistrados não são eleitos pelo voto popular direto, mas sim por intermédio de certame público para ingresso na magistratura ou por intermédio de escolha do chefe do Executivo, na parte e nas situações específicas em que o texto constitucional determina.

Tal circunstância desencadeia discussão acerca da ausência de legitimidade democrática das decisões 
emanadas do Poder Judiciário, principalmente aquelas que trazem em seu conteúdo direitos supraindividuais, atingindo, direta ou indiretamente, um número, em vezes, indeterminado de cidadãos, a exemplo das famosas ordens judiciais de bloqueio do aplicativo de mensagem instantânea WhatsApp, que afeta não apenas o caso concreto, mas a comunicação de um número indeterminado de pessoas, ou as decisões polêmicas tomadas em sede de controle concentrado de constitucionalidade.

Em vezes, as decisões do Poder Judiciário, sobretudo do Supremo Tribunal Federal afetam, ainda que reflexamente, parcela significativa da sociedade, sem a manifestação democrática de ao menos parte dela, direta ou indiretamente atingida, cuja decisão, repita-se, foi emanada de poder cujos membros não foram eleitos pela população.

Com efeito, o debate acerca da legitimidade e democratização oriundas das decisões emanadas do Poder Judiciário, notadamente em tempos da judicialização de políticas públicas e da incidência do chamado ativismo judicial, vem ganhando largo campo.

Ganha acentuada relevância a realização de audiências públicas e a participação do amicus curiae, calcado, sobretudo, sob dois aspectos fundamentais.

O primeiro diz respeito à legitimação da própria atividade jurisdicional, ao qual a um só tempo se atenta a conferir acesso amplo ao direito fundamental de acesso à justiça, possibilitando a participação de parcela da sociedade em determinada ação específica, democratizando-a, eis que dá voz aos interessados.

O segundo aspecto diz respeito ao aperfeiçoamento da decisão judicial, na medida em que a utilização desses instrumentos democráticos possibilita ao magistrado, destinatário final da prova, a colheita de elementos técnicos e científicos para o melhor julgamento da causa e, como consectário lógico, melhor aplicação do direito ao caso.

\section{DA FIGURA DA AUDIÊNCIA PÚBLICA}

Audiências públicas consubstanciam-se em reuniões, esporádicas ou periódicas, organizadas e realizadas por determinada classe da sociedade civil, visando discutir problemas e soluções acerca de assuntos ou direitos específicos.

Realizadas a longa data, essencialmente perante o Legislativo e Executivo, possibilita que a população discuta, apresentando os problemas efetivos e eventuais soluções, assuntos ou direitos específicos, bem como seu controle perante os Poderes da República e a administração pública, dando transparência aos atos, legitimando e democratizando-os.

Quanto à sua origem, observa-se que "este instrumento é oriundo do "direito anglo-saxão, 
fundamentado no direito inglês e no princípio de justiça natural, e no direito norte-americano, ligada ao princípio do devido processo legal"(BOSCO, 2002, p. 148).

Trata-se de uma verdadeira arena de debates, permitindo a participação de diversos atores da sociedade no enfrentamento de problemas e tomada de decisões emanadas dos Poderes da República e órgãos da administração direta e indireta, com vistas a assegurar a democracia representativa.

Traduz-se em um importante instrumento de participação democrática em favor da população perante os Poderes da República, retratando exatamente o que se qualifica de poder representativo democrático social, direito fundamental, sendo certo que "quanto mais o processo de democratização avança, mais o homem se vai libertando dos obstáculos que o constrangem e mais liberdade é conquistada”(SILVA, 2005, p. 234) Nas palavras de Evanna Soares:

A audiência pública é uma das formas de participação e de controle popular da Administração Pública no Estado Social e Democrático de Direito, propiciando ao particular a troca de informações com o administrador. bem assim o exercício da cidadania e o respeito ao princípio do devido processo legal em sentido substantivo. Seus principais traços são a oralidade e o debate efetivo sobre matéria relevante, comportando sua realização sempre que estiverem em jogo direitos coletivos. (SOARES, 2.002, p. 259)

A Constituição Federal de 1988 prevê expressamente a sua possibilidade de realização, pelas comissões do Congresso Nacional, quando da discussão de projetos de lei (artigo $58, \$ 2^{\circ}$, II).

Com isso, o constituinte originário implicitamente deixa um recado aos parlamentares e administradores públicos, no sentido de que os mandatos a eles conferidos pressupõem, também, ouvir a voz dos seus eleitores e da sociedade civil no enfrentamento e tomada das decisões.

Ou seja, ao cidadão cabe o exercício para além de votar e escolher seus representantes, mas também participar efetiva e ativamente dos atos e ações executadas pelo Estado, em quaisquer de seus poderes.

A título exemplificativo do poder da participação democrática, a elaboração da Lei no 12.965/14, popularmente conhecida como Marco Civil da Internet, que estabelece princípios, garantias, direitos e deveres para o uso da Internet no Brasil, contou com amplo apoio e participação da sociedade civil, especialmente da academia.

Algumas leis prevêem expressamente a realização de audiência pública, como por exemplo, a Lei no 9.478/97 que em seu artigo 19 estabelece a obrigatoriedade de sua realização para a alteração de normas administrativas que impliquem afetação de direito dos agentes econômicos ou de consumidores e usuários de bens e serviços das indústrias de petróleo, de gás natural ou de biocombustíveis; a Lei no 8.666/93, popularmente conhecida como Lei de Licitação, que em seu artigo 39 impõe o uso deste instrumento nas hipóteses em que o valor do objeto licitado for superior a cento e cinquenta milhões de reais, bem como a Lei n 9.784/99, responsável por regular o processo administrativo perante a Administração Pública Federal, que através do seu 
artigo 32 expressamente disciplina que poderá ser aberto audiência pública nas discussões que envolver determinado interesse geral.

Inobstante a frequente utilização pelo Legislativo e Executivo, referido instrumento de participação democrática, ao longo dos anos, vem sendo utilizado de forma crescente pelo Poder Judiciário, sobretudo no âmbito do Supremo Tribunal Federal.

Sua utilização vem a calhar com a critica tecida ao Poder Judiciário, no sentido de que seus membros não possuem legitimidade democrática ou, quando muito, limitada, na medida em que, diferentemente do que ocorrem com os membros dos demais poderes, não foram eleitos democraticamente pelo povo, não sendo, pois, seus representantes constituídos.

Soma-se a isso ao fato de que, em muitas demandas, o direito material discutido afeta, direta ou indiretamente, um número indeterminado de pessoas, como por exemplo, no caso dos direitos difusos e coletivos, sendo, pois, importante a participação democrática da população para legitimar e democratizar as decisões judiciais.

As audiências públicas na esfera do Judiciário têm papel fundamental de exercício da democracia, na medida em que ao dar voz a parcela da sociedade atingida, estende-se o acesso à justiça, que deve ser interpretado de forma ampla, não a apenas ao direito de provocar a atividade jurisdicional ou compor o polo de uma relação jurídico-processual, mas a manifestar-se perante a autoridade judicante em situações de interesse supraindividual.

Acerca da concepção ampla do direito fundamental de acesso à justiça, segundo as lições clássicas de Cappelletti e Garth:

$\mathrm{O}$ acesso à justiça pode, portanto, ser encarado como o requisito fundamental - o mais básico dos direitos humanos - de um sistema jurídico moderno e igualitário que pretende garantir, e não apenas proclamar os direitos de todos. (CAPPELLETTI; GARTH, 1988, p.12).

Com efeito, a realização de audiências públicas garante a participação dos jurisdicionados nas decisões do Poder Judiciário, traduzindo de forma efetiva a concepção ampla do direito fundamental de acesso à justiça.

Além disto, subsidia o julgador para a boa aplicação do direito, possibilitando ao magistrado, destinatário final da prova, a colheita de elementos técnicos e científicos que circundam a lide e, em vezes, escapam da ciência eminentemente jurídica, como por exemplo, questões ligadas à ciência exata como a criptografia, tema em voga, e a ciência biológica, como as controvérsias acerca da utilização de células-tronco.

O legislador infraconstitucional atento a importância das audiências públicas, estimulou sua utilização quando do processamento e julgamento da Arguição de Descumprimento de Preceito Fundamental (artigo 6, da Lei no 9.882/99), Ações Direta de Inconstitucionalidade e Declaratórias de Constitucionalidade (artigo 9º da Lei no 9.868/99). 
Ou seja, desde o ano de 1.999 há previsão legal para a realização de audiências públicas na esfera do Supremo Tribunal Federal quando do processamento das ações constitucionais concentradas.

Contudo, em que pesem as referidas leis terem sido promulgadas em 1.999, as audiências públicas no âmbito do Supremo Tribunal Federal ganharam corpo efetivamente a partir de 2.007, tendo como caso pioneiro o debate pluralizado da discussão contida na Ação Direta de Inconstitucionalidade n 3.510, que versava sobre a controvérsia acerca de inconstitucionalidade de alguns dispositivos da Lei no $11.105 / 05$, popularmente conhecida como Lei de Biossegurança e, objetivava como pano de fundo, aferir se o uso de célulastronco embrionárias em pesquisas científica para fins terapêuticos era constitucional.

Na ocasião, a audiência pública foi convocada pelo Supremo Tribunal Federal pelo então Ministro Ayres Brito, tendo ocorrido em 20 de abril de 2.007 com a participação de diversas entidades representativas da sociedade civil, como por exemplo, o Movimento em Prol da Vida - MOVITAE e o Instituto de Bioética, Direitos Humanos e Gênero.

A realização da audiência pública nesta ação que, de modo efetivo, transcendia em seu objeto a ciência eminentemente jurídica, foi essencial para o aperfeiçoamento da decisão proferida pelo Supremo Tribunal Federal nos autos da mencionada Ação Direta de Inconstitucionalidade no 3.510, tendo ao final sido proferido decisão majoritária julgando improcedente a ação concentrada, com o consequente afastamento de inconstitucionalidade da Lei de Biossegurança, calcada em fundamentos não apenas jurídicos, mas técnicocientíficos.

Após este precedente, houve uma crescente, ano após ano, de realização de audiências públicas, como citamos: a judicialização do direito a saúde (suspensão de liminar no 47 e 64); a interrupção de gravidez nos casos de feto anencéfalo (Arguição de Descumprimento de Preceito Fundamental no 54); discussão acerca das políticas de ação afirmativa de acesso ao ensino superior (Arguição de Descumprimento de Preceito Fundamental no 186); a proibição do uso de amianto (Ação Direta de Inconstitucionalidade no 3.937); a possibilidade de publicação de biografias não autorizadas (Ação Direta de Inconstitucionalidade no 4.815), dentre outras tantas ações concentradas e difusas já julgadas.

Mediante a realização de audiências públicas no âmbito do Judiciário, especialmente perante o Supremo Tribunal Federal, vem sendo promovido um diálogo aberto e plural, de esclarecimentos técnico-científicos, outros olhares e pontos de vista sobre a questão, para que se possam colher mais subsídios para o deslinde da controvérsia sub judice.

Tamanha a importância tomada por este instrumento jurídico, a ponto do novo Código de Processo Civil estimular sua utilização perante o Poder Judiciário de um modo geral, ou seja, para além das hipóteses 
previstas nas Leis 9.882/99 e 9.868/99 que se limitavam a prever seu cabimento nas ações concentradas, alargando sua admissão tanto para contribuir com a rediscussão da tese jurídica adotada em enunciado de súmula ou em julgamento de casos repetitivos (artigo 927, $\$ 2^{\circ}$ ), como nos casos de incidente de resolução de demandas repetitivas (artigo 983, \$1 $1^{\circ}$.

\section{O BRASIL COMO UMA DEMOCRACIA PARTICIPATIVA E A IMPORTÂNCIA DAS AUDIÊNCIAS PÚBLICAS}

A democracia tem como objetivo a proteção dos direitos humanos, como as liberdades de expressão e religião, a proteção legal, e as oportunidades de participação na vida política, econômica, e cultural da sociedade. Pressupõe um regime político em que a soberania é exercida pelos cidadãos, de forma direta, indireta ou semidireta.

Em verdade, "todo poder político, em um ambiente democrático, é exercido em nome do povo e deve contas a sociedade"(BARROSO, 2014, p. 18).

Na democracia eminentemente direta, o cidadão vota e expressa sua opinião sem intermediários, sem a participação de representantes políticos, como era comumente exercido nas praças públicas na Grécia antiga, berço da democracia.

Contudo, em tempos contemporâneos, esse modelo de democracia encontra-se superado nas principais nações.

Por sua vez, na democracia indireta, tradicionalmente ocorre o que se denomina de democracia representativa, situação em que as decisões não são tomadas diretamente pelos cidadãos, mas por intermédio de representantes políticos eleitos através de voto direto.

$\mathrm{Na}$ democracia indireta, há, pois, outorga de poderes para que representantes políticos defendam os interesses dos seus eleitores.

Embora as constituições brasileiras tenham sempre enunciado um sistema representativo, só nos momentos democráticos que isso de fato se deu. A Constituição de 1988, após 20 anos de ditadura militar, resgatou este sistema verdadeiramente democrático e representativo no Brasil, que adota hoje uma democracia semidireta ou participativa, conjugando a escolha de representantes com a participação efetiva e direta dos cidadãos.

Em seu preâmbulo o texto constitucional já destaca a representação popular, enquanto o artigo $1^{\circ}$, parágrafo único, dispõe que "todo poder emana do povo, que o exerce por meio de representantes eleitos ou 


\section{diretamente, nos termos desta Constituição."}

Em inúmeras outras passagens, o texto constitucional externa instrumentos para o exercício da democracia representativa, afirmando, por exemplo, que "a soberania popular será exercida pelo sufrágio universal e pelo voto direto e secreto, com valor igual para todos, e, nos termos da lei, mediante: plebiscito; referendo; e iniciativa popular de lei".

Acerca da democracia semidireta e participativa, pontua Carlos Simões:

O Estado de direito torna-se também democrático quando passa a ter por fundamento a participação da população, conforme o parágrafo único do art. $1^{\text {a }}$ da $\mathrm{CF}$, por meio de conselhos (art. 194, inciso VII), referendo e plebiscito (art. 49, inciso XV) e iniciativa popular (art. 29, inciso XIII, e art. 61, parágrafo 2o da CF), democrático porque reconhece não somente os conflitos políticos, como também os sociais, criando instituições para resolvê-los e promovendo programas e projetos de reforma, instituindo os direitos sociais e promovendo a participação das coletividades (conselhos) na formulação das políticas públicas. (SIMÕES, 2014, p. 103)

A carta constitucional prevê todos os instrumentos de exercício direto da democracia, a exemplo do plebiscito (artigos 14 e 18, $\$ 4^{\circ}$ ); referendo (artigos 14, II e 84, VIII) e; iniciativa popular de projeto de lei (artigo 29, XIII).

Sem dúvida, as audiências públicas revelam-se um instrumento essencial na consolidação desta democracia participativa. Todos os Poderes podem e devem utilizar este instrumento jurídico, sendo pertinente em inúmeras situações, como por exemplo, na discussão de determinado projeto de lei, embate sobre questões fiscais e orçamentárias e em ações judiciais, principalmente as que carregam questões ligadas a matéria supraindividual.

Ou seja, embora o constituinte originário tenha previsto a realização de audiências públicas apenas perante o Congresso Nacional (artigo 58, \$2 , II), o legislador infraconstitucional (como no Código de Processo Civil) estendeu a representação deste instrumento democrático na seara dos demais poderes, tendo sido largamente utilizado, pois, não apenas pelo Legislativo, mas também pelo Executivo e Judiciário, sobretudo pelo Supremo Tribunal Federal.

Por intermédio das audiências públicas, a sociedade ganha voz ativa perante as ações executadas pelos poderes, legitimando e democratizando os atos emanados pelo Estado.

Assim, a execução da audiência pública se amolda com o exercício da democracia participativa, eis que não obstante a outorga de representação conferida aos atores políticos, à sociedade civil efetiva e diretamente participa da discussão e debate de determinado direito e tomada de decisão a ser tomada pelo Estado.

Este instrumento de participação democrática ganha ainda mais destaque quando é utilizado no âmbito do Judiciário, sobretudo do Supremo Tribunal Federal, eis que sua realização garante a participação efetiva dos jurisdicionados, traduzindo de forma ampla a concepção de acesso à justiça, bem como a um só tempo 
pluralizando e democratizando o debate constitucional, com vistas a assegurar melhor eficiência da atividade jurisdicional.

\section{DA FIGURA JURÍDICA DO AMICUS CURIAE}

Amicus curiae qualifica-se como colaborador da Corte Julgadora, objetivando subsidiar o magistrado com elementos técnicos e científicos acerca da matéria objeto da controvérsia sub judice que envolve temas multidisciplinares e direitos supraindividuais, atuando como terceiro autônomo e, em tese, sem interesse direto na causa, visando à correta aplicação do direito, propiciando maior eficiência da atividade jurisdicional.

Em verdade, "é um instituto de matiz democrático, uma vez que permite que terceiros penetrem no mundo fechado e subjetivo do processo para discutir objetivamente teses jurídicas que vão afetar toda a sociedade"(MACIEL, 2001, p. 07)

Quanto a sua etimologia, "há forte opinião de que a origem do amicus curiae está na Inglaterra, no processo penal, embora haja autores que afirmem haver figura assemelhada já no direito romano." (BUENO, 2008, pág. 83)

Esta figura jurídica possui destacada atuação em âmbito internacional, principalmente nos países adeptos a common law, como na Inglaterra e Estados Unidos, neste último, adotado com grande influência na Suprema Corte desde o início do século XX.

No Brasil, a primeira aparição, ainda que de forma tímida, do amicus curiae ocorreu com o advento da Lei $n^{\circ} 4.726 / 65$, ao qual em seu artigo 32 alçava como terceiro interessado as Juntas Comerciais em lides relacionadas aos seus interesses institucionais.

Destaca-se, em seguida, a promulgação da Lei no 6.616/78, ao qual em seu artigo 31 provoca a Comissão de Valores Imobiliários - CVM a manifestar-se sobre processos que versavam sobre matéria no âmbito de sua competência.

Sua participação encontra previsão no âmbito da Suprema Corte brasileira, quando do processamento e julgamento da Arguição de Descumprimento de Preceito Fundamental (artigo 6º da Lei no 9.882/99), ou das Ações Direta de Inconstitucionalidade e Ações Declaratórias de Constitucionalidade (artigo 9º, da Lei no 9.868/99)

Contudo, a ausência de previsão legal não impediu a participação desta figura jurídica em ações difusas.

O primeiro caso de atuação de amicus curiae perante o Supremo Tribunal Federal ocorreu na ação que discutiu a restituição de ICMS em casos de substituição tributária, quando há diferença entre o valor da venda e o preço presumido (Ação Direta de Inconstitucionalidade no 2777), cuja admissão desta figura jurídica ocorreu em 
25 de novembro de 2003, por deferimento do então Relator Ministro Cezar Peluso.

De lá para cá, desde seu primeiro precedente, inúmeras ações foram julgadas ou ainda estão em curso com a manifestação do amicus curiae, a exemplo da ação que reconheceu como entidade familiar as uniões homoafetivas estáveis, equiparando-a a relação estável entre homem e mulher (Arguição de Descumprimento de Preceito Fundamental n 132); na ação em que se discutiu a proibição da construção de postos de gasolina nos estacionamentos de hipermercados, teatros, cinemas, shopping centers, escolas e hospitais públicos no Distrito Federal (Recurso Extraordinário n 597165); na lide que discutia a constitucionalidade da incorporação de quintos por servidores públicos em função do exercício de funções gratificadas no período compreendido entre a edição da Lei 9.624/1998 e a Medida Provisória 2.225-45/2001 (Recurso Extraordinário nº 638115) e, recentemente, na discussão ainda sub judice acerca da possibilidade de execução imediata da pena depois de decisão condenatória confirmada em segunda instância (Ações Declaratórias de Constitucionalidade 43 e 44).

Relevante trabalho acadêmico sobre a temática, no qual fora realizado minucioso estudo empírico da atuação desta figura perante o Supremo Tribunal Federal, ao final aponta que "o ingresso do amicus curiae contribui positivamente para o aumento das alternativas interpretativas do processo de tomada de decisóes, promovendo a abertura procedimental e a pluralização da jurisdição constitucional” (MEDINA, 2008, p. 188).

No Superior Tribunal de Justiça, destaca-se a atuação do amicus curiae no julgamento do Recurso Especial no $1.339 .313 / \mathrm{RJ}$, ao qual se discutiu a (i) legitimidade da cobrança de tarifa na prestação de serviço de coleta e transporte de dejetos.

Ou seja, embora não previsto expressamente no Código de Processo Civil de 1.973, mas em legislações esparsas, a jurisprudência, essencialmente a da Suprema Corte, já reconhecia sua importância, relevância e legitimidade democrática.

Percebe-se, assim, que a até então omissão ou deficiência legislativa acerca da regulamentação da participação efetiva do amicus curiae, nunca foi empecilho para atuação desta figura jurídica em lides de grande relevância, principalmente nos tribunais superiores.

Em que pese isso, tamanha a importância alçada à figura do amicus curiae nos últimos anos que o legislador tratou de inseri-lo expressamente no novo Código de Processo Civil, através do artigo 138 e seguintes, inclusive com o propósito de delimitar alguns pontos, esclarecer divergências e estabelecer seu alcance de atuação e efetivos poderes.

Com efeito, através da promulgação do novo Código de Processo Civil, ocorrido em março de 2015, taxativamente passou-se a admitir a participação efetiva desta figura jurídica em todas as fases do processo, isto é, inclusive em primeiro grau de jurisdição. 
O ingresso do amicus curiae se dá de ofício ou por solicitação formal deste terceiro interveniente, no prazo de quinze dias, desde que presentes os pressupostos para sua admissão, quais sejam: (i) relevância da matéria, a especificidade do tema objeto da demanda ou a repercussão social da controvérsia e; (ii) pessoa natural ou jurídica com expertise e elevada representatividade.

Acerca da sua admissão, destaca Gustavo Binenbojm:

De acordo com autorizado magistério da doutrina e a jurisprudência recente do Supremo Tribunal Federal, a postulação de intervenção nos autos da ação direta (ou representação por inconstitucionalidade), na condição de amicus curiae, pode se dar, como se assentou, até a fase final da instrução processual, mas antes de iniciado o julgamento final da causa. (BINENBOJM, 2007, p. 94)

Os poderes deste terceiro interveniente deverão ser traçados pelo julgador que solicita ou admite a intervenção, no momento de sua admissão, sendo certo, todavia, que não se admitirá a interposição de recursos autônomos, ressalvado a hipótese de manejo de embargos declaratórios e do feito que julgar o incidente de resolução de demandas repetitivas.

Além das regras trazidas pelo Código de Processo Civil, o Supremo Tribunal Federal firmou sólida jurisprudência sobre a temática, como por exemplo, reconhecendo que além de entidades representativas, até mesmo pessoa natural com expertise sobre o tema posto pode figurar como está figura jurídica, conforme deliberado por maioria no plenário nos autos do Mandado de Segurança nº 32033.

Com a positivação, delimitação de poderes e a pacificação de alguns pontos trazidos pelo novo Código de Processo Civil, ao menos em tese, a tendência é uma participação ainda maior desta figura jurídica, em todos os graus de jurisdição, mas notadamente no âmbito de Supremo Tribunal Federal, para o fim de se atingir o resultado útil do processo, com a melhoria da prestação da atividade jurisdicional.

\section{AUDIÊNCIAS PÚBLICAS E AMICUS CURIAE NO ÂMBITO DO SUPREMO TRIBUNAL FEDERAL INSTRUMENTOS DE APERFEIÇOAMENTO E LEGITIMIDADE DAS DECISÕES}

Embora inexista hierarquia entre os Poderes da República que são independentes e devem ser harmônicos entre si, o Judiciário nos últimos anos vem ganhando cada vez mais protagonismo, instado a se manifestar sobre inúmeras questões.

Isso decorre por diversos fatores, seja em decorrência da litigiosidade corriqueira, haja vista a cultura da sentença aqui enraizada; face a inércia ou omissão dos demais poderes em exercer suas funções tipicamente constitucionais, sendo bom observar que estamos vivendo em tempos de aguda judicialização de políticas públicas; em decorrência da critica do chamado exercício do ativismo judicial ou, por fim, ante a força atribuída 
pelo legislador ao outorgar ao Supremo Tribunal Federal a elaboração da súmula vinculante que, como próprio nome sugere, cuja vinculação os demais órgãos judicantes e à administração pública direta e indireta, nas esferas federal, estadual e municipal.

Segundo os apontamentos de Oscar Vilhena Vieira:

O STF está hoje no centro do nosso sistema político, fato que demonstra a fragilidade de nosso sistema representativo. Tal tribunal vem exercendo, ainda que subsidiariamente, o papel de criador de regras, acumulando a autoridade de interprete da Constituição com o exercício de Poder Legislativo, tradicionalmente exercido por poderes representativos. (VILHENA, 2008.p. 441).

Por sua vez, segundo Luis Roberto Barroso:

Questões relevantes do ponto de vista político, social ou moral estão sendo decididas pelo Judiciário. Trata-se, como intuitivo, de uma transferência de poder das instâncias tradicionais, que são o Executivo e o Legislativo, para juízes e tribunais. (BARROSO, 2014, p. 16)

Houve, pois, nos últimos anos uma expansão da autoridade da Suprema Corte brasileira em relação aos demais poderes, embora a ressalva de que ambos devam subsistir harmonicamente para o regular funcionamento do Estado Democrático de Direto.

A seu turno, critica se faz em decorrência da suposta e pretensa ausência de representatividade democrática do Poder Judiciário, o que em tese fragilizaria sobremaneira a legitimidade das suas decisões que, em vezes não raras, principalmente em tempos que se visa a estimulação das ações coletivas sobre as demandas individuais, possui potencial suficientemente capaz de afetar a esfera de direitos de um número grande de usuários que sequer figuram como parte na lide posta a apreciação judicial.

Acerca dos fundamentos da suposta ausência de representatividade democrática e legitimidade do Poder Judiciário, Luis Roberto Barroso destaca:

Inúmeras criticas tem sido dirigidas Inúmeras críticas têm sido dirigidas a essa expansão do papel do Judiciário. A primeira delas é de natureza política: magistrados não são eleitos e, por essa razão, não deveriam poder sobrepor sua vontade à dos agentes escolhidos pelo povo. A segunda é uma crítica ideológica: o Judiciário seria um espaço conservador, de preservação das elites contra os processos democráticos majoritários. Uma terceira crítica diz respeito à capacidade institucional do Judiciário, que seria preparado para decidir casos específicos, e não para avaliar o efeito sistêmico de decisões que repercutem sobre políticas públicas gerais. E, por fim, a judicialização reduziria a possibilidade de participação da sociedade como um todo, por excluir os que não têm acesso aos tribunais. (BARROSO, 2014, p. 16/17)

Por sua vez, "entre os três Poderes da República, o Judiciário é o menos conhecido e mais distante da sociedade, situação que favorece uma crise de legitimidade” (BARBOSA, 2006, pág. 02)

Assim, o Poder Judiciário, não obstante a ter em sua composição membros não eleitos pela população 
através de voto direto, é acusado por parte da doutrina de ser o poder mais distanciado da sociedade civil que, supostamente, não participa efetivamente dos atos administrativos e decisórios emanados.

No entanto, referidas criticas podem ser mitigadas, eis que a emenda constitucional $\mathrm{n}^{\circ} 45$, dentre outras disposições, criou o Conselho Nacional de Justiça, para o fim de controlar a atuação administrativa, disciplinar e financeira dos órgãos do Judiciário brasileiro, cuja composição é multissetorial, sendo composto tanto por magistrados, como por membros do Ministério Público, da advocacia e cidadãos representantes da sociedade civil.

Logo, a própria composição e atuação do Conselho Nacional de Justiça acaba por romper um importante paradigma no sentido de ser o Poder Judiciário, supostamente, imune de controle e participação da sociedade civil no que concerne a sua atuação disciplinar, administrativa e orçamentária, eis que referido Conselho da voz a diversos atores, incluindo a sociedade civil.

Se não bastasse isso, ainda afastando o argumento da suposta ausência de representatividade democrática do Poder Judiciário, é necessário observar que a função constitucional precípua do Judiciário difere dos demais, não podendo equipará-las as funções tipicamente constitucionais exercidas tanto pelo Parlamento, quanto pelo Executivo.

Soma-se a isso a circunstância de que, em verdade, "uma democracia não é feita apenas e somente da vontade das maiorias, mas também da preservação do direito fundamental de todos." (BARROSO, 2014, p. 17).

Assim, tanto a natureza da função tipicamente constitucional exercida pelo Judiciário, como a legitimidade atribuída a este poder pelo próprio texto constitucional e, por fim, a participação de membros não magistrados (conselheiros do Conselho Nacional de Justiça), em tese são suficientes para afastar a critica acerca de sua ausência de representatividade democrática e legitimidade.

A despeito desta relevante discussão, ao qual inequivocamente merece reflexões, as decisões emanadas pelo Supremo Tribunal Federal afetam, direta ou indiretamente, um número indeterminado de pessoas.

Bem por isso, a comunidade jurídica cada vez mais tem estimulado e, na pratica, efetivamente utilizado as audiências públicas e o amicus curiae na esfera do Judiciário, sobretudo no âmbito do Supremo Tribunal Federal, aperfeiçoando, legitimando e democratizando suas decisões.

A participação de tais figuras jurídicas, não obstante a trazer em seu corpo democratização pluralizadora da decisão proferida pelo Supremo Tribunal Federal, legitimando-a, tem potencial suficiente para qualificá-la, na medida em que os magistrados, antes de prolatarem seus respectivos votos, contam com subsídios técnicos e científicos de questões que, em vezes, escapam da ciência jurídica, como célula troco, criptografia e etc.

Vale registrar que a atuação de amicus curiae em determinado caso não obsta a convocação para a 
realização de audiências públicas, sendo que ambos os instrumentos democráticos subsistem harmonicamente, pluralizando o debate constitucional sub judice, democratizando, legitimando e subsidiando os julgadores quando da prolação da decisão.

E mais. O alto índice de judicialização de políticas públicas sub judice, ao qual em muitas ocasiões traz no conteúdo da discussão questões que transcendem a ciência eminentemente jurídica, faz com que seja prudente a promoção do diálogo junto à sociedade civil, inclusive para que a decisão proferida seja a mais técnica possível.

E, quanto mais técnica e fundamentada revestir-se a decisão judicial, mais próximo estar-se-á da tão clamada eficiência da atividade jurisdicional.

Análise individualizada de cada um dos acórdãos nas lides mencionadas neste trabalho acadêmico que tiveram tanto a participação do amicus curiae, como realização de audiências públicas, demonstram que as contribuições elencadas foram fundamentais para o aperfeiçoamento e aprimoramento da decisão, por um lado legitimando e pluralizando o debate constitucional e, de outro, proporcionando elementos técnico-científico para a eficiência da atividade jurisdicional.

Outras ações contendo gigante repercussão geral, tanto do ponto de vista social, jurídico, político e econômico, estão em curso perante o Supremo Tribunal Federal pendente de julgamento, sendo que já contaram ou contam com a realização de audiências públicas e participação atuante de amicus curiae.

Neste sentido, ainda em curso aguardando julgamento podemos citar, dentre outros, a discussão da aplicabilidade (ou não) do direito ao esquecimento na esfera civil quando esse for invocado pela própria vítima ou por seus familiares (Recurso Extraordinário no 1010606), a discussão sobre a possibilidade de suspensão do aplicativo WhatsApp e demais aplicativos de comunicação instantânea por decisão judicial (Arguição de Descumprimento de Preceito Fundamental no 403), bem como a legalidade (ou não) de prisão do denunciado após decisão condenatória proferida pela segunda instância, ou seja, mesmo antes do trânsito em julgado da ação penal (Ações Declaratórias de Constitucionalidade no 43 e 44).

Com efeito, percebe-se que o Supremo Tribunal Federal com muito bons olhos aderiu de forma abundante a participação do amicus curiae e a realização de audiências públicas tanto nas ações de controle concentrada, como as de controle difuso, sendo certo que este instrumento de democracia vem sendo, ano após ano, largamente utilizado, o que vem demonstrando a preocupação dos magistrados em legitimar e aperfeiçoar as decisões emanadas pela Corte, propiciando a eficiência da atividade jurisdicional.

Do mesmo modo, percebe-se a preocupação do Parlamento em promulgar leis que incentivem a realização de audiências públicas e a participação de amicus curiae nas demandas judiciais, a exemplo das regras trazidas pelo novo Código de Processo Civil que visam dar maior amplitude aos referidos instrumentos jurídicos. 
Tanto o amicus curiae como as audiências públicas representam eficazes instrumentos de participação democrática, promovendo a ampliação do acesso a jurisdição constitucional, outorgando voz à sociedade civil, bem como aproximando os jurisdicionados do Poder Judiciário, criticado por ser o poder mais distante e apartado dos cidadãos, sendo que a intervenção de tais figuras jurídicas, de uma só vez aperfeiçoa, democratiza e legitima as decisões judiciais proferidas, essencialmente na âmbito do Supremo Tribunal Federal.

\section{CONCLUSÕES}

Sendo o ser humano o centro da ordem jurídica, sua participação efetiva nos atos e decisões tomadas pelos Poderes da República e órgãos da Administração de um modo geral é de rigor, conceito basilar do Estado Democrático de Direito de qualquer democracia.

A participação representativa democrática dos cidadãos vai muito além do direito de eleger seus representantes, não podendo haver seu distanciamento na tomada de decisão dos Poderes da República.

Há tempos, o Poder Judiciário, sobretudo na figura do Supremo Tribunal Federal, vive uma crise de representatividade, sendo que não obstante aos seus membros não terem sido eleitos através de voto direto, é acusado por parte da doutrina de ser o poder mais afastado, apartado e distanciado dos cidadãos.

Contudo, ao passo que vivencia essa crise, o Poder Judiciário encontra-se cada vez mais em evidência, seja em decorrência da critica do chamado exercício do ativismo judicial, face a elevada judicialização das políticas públicas ou ante a força atribuída pelo legislador ao outorgar ao Supremo Tribunal Federal a elaboração da sumula vinculante.

Em que pese a emenda constitucional no 45 ter instituído o Conselho Nacional de Justiça, órgão multissetorial composto por membros do Ministério Público, da advocacia e cidadãos representantes da sociedade civil com a função precípua de controlar a atuação administrativa, financeira e correcional dos órgãos do poder Judiciário brasileiro, tal figura obviamente não atende por si só e, em sua plenitude, a necessidade de possibilitar a representação democrática dos atos eminentemente jurisdicionais.

Soma-se a isso o fato de que o Supremo Tribunal Federal, tem alcance de com suas decisões atingir parcela significativa da sociedade, inclusive a esfera de direitos, ainda que indiretamente, de pessoas que sequer compõe a relação jurídico-processual.

É preciso garantir, assim, a participação democrática da população essencialmente em casos que envolvem direitos supraindividuais, para o fim de pluralizar a discussão constitucional judicializada, dando voz a quem de direito, concebendo de forma ampla e abrangente a aplicação efetiva do direito fundamental do acesso a justiça, ao qual se fundamenta na possibilidade dos jurisdicionados acessarem a máquina judiciária não apenas 
como parte na relação processual, mas como terceiro interveniente que quer ver a boa aplicação do direito ao caso posto, a eficiência da atividade jurisdicional.

Tanto o constituinte originário quanto o legislador infraconstitucional vêm se preocupando em salvaguardar e introduzir no ordenamento jurídico instrumentos efetivos de poder representativo democrático social, como ocorre com as audiências públicas, ao qual se consubstancia em uma verdadeira arena de debates, possibilitando a participação de diversos atores da sociedade no enfrentamento de problemas e tomada de decisões emanadas dos Poderes da República e órgãos da administração direta e indireta.

Logo, sua realização amplia a possibilidade de acesso a jurisdição constitucional, subsidiando os magistrados com contribuições técnicas visando à boa aplicação do direito ao caso em concreto, a eficiência da atividade jurisdicional.

No âmbito do Supremo Tribunal Federal, este instrumento de representação popular vêm sendo largamente utilizada desde o ano de 2007, notadamente em casos envolvendo temas específicos de outras ciências, como exatas e biológicas, fazendo-se, de fato, necessária a intervenção de setores e atores diversos da sociedade para pluralizar o debate constitucional, aperfeiçoando e legitimando as decisões judiciais proferidas.

Na mesma direção, o amicus curiae também se revela essencial para subsidiar o julgador com elementos técnicos e científicos acerca da matéria objeto da controvérsia levada à apreciação judicial, visando à correta aplicação do direito. Sua participação, igualmente viabiliza uma adequada resolução do litígio constitucional, pluralizando, democratizando e legitimando as decisões judiciais, sobretudo do Supremo Tribunal Federal.

Análise individualizada de ações que contaram com a realização de audiências públicas e/ou participação de amicus curiae revelam que a decisão judicial torna-se mais técnica, eis que subsidiada com maiores elementos, aperfeiçoando as decisões.

Assim, tanto a audiência pública como a participação do amicus curiae perante o Poder Judiciário, sobretudo no âmbito do Supremo Tribunal Federal, de uma só vez tem o condão de aproximar os jurisdicionados deste poder, criticado por supostamente ser o mais distante dos cidadãos, conferindo aplicação a espécie do acesso à justiça, bem como subsidiar os magistrados com contribuições técnicas visando à boa aplicação do direito, ou seja, a eficiência da atividade jurisdicional. 


\title{
THE ROLE OF AMICUS CURIAE AND PUBLIC HEARINGS AS INSTRUMENTS FOR THE IMPROVEMENT AND LEGITIMACY OF THE DECISIONS OF THE SUPREME FEDERAL COURT
}

\begin{abstract}
The purpose of this article is to understand the importance of the amicus curiae and public hearings as instruments that improve judicial decisions, as well as legitimize the Judiciary, specifically within the scope of the Federal Supreme Court. On the one hand, the amicus curiae acts as an autonomous third party with no direct interest in the lide, which does not comprise any of the poles of the procedural relation set in court, but it assists judges in eminently technical and juridical matters, especially those with repercussions General and with contents of collective and diffuse rights, aiming at the correct application of the right to the concrete case, propitiating the efficiency of the jurisdictional activity. On the other hand, holding public hearings broadens the debate on the subject under judicial review, which ensures greater participation of the social entities involved or effectively affected by the decision to be made, ensuring both the democratization of access to justice itself and legitimizing the decisions of the Federal Supreme Court.
\end{abstract}

Keywords: Amicus Curiae. Public hearings. Improvement of the judicial tribunals of the Federal Supreme Court. Instruments of legitimation and democratization.

\section{REFERENCIAS}

BARBOSA, Cláudia Maria. O processo de legitimação do poder judiciário brasileiro. In: XIV Congresso Nacional do CONPEDI-2006, Fortaleza. Anais do XIV Congresso Nacional do CONPEDI. Florianópolis: Fundação Boiteux. 2006.

BARROSO, Luís Roberto. O constitucionalismo democrático no Brasil: crônica de um sucesso imprevisto. Neoconstitucionalismo em perspectiva. Viçosa: UFV, 2014.

BINENBOJM, Gustavo. A dimensão do amicus curiae no processo constitucional brasileiro: requisitos, poderes processuais e aplicabilidade no âmbito estadual. A\&C-Revista de Direito Administrativo \& 
Constitucional, v. 5, n. 19, p. 73-95, 2007

BONAVIDES, Paulo. Teoria constitucional da democracia participativa. São Paulo: Malheiros, 2001.

BUENO, Cassio Scarpinella. Amicus curiae no Processo Civil brasileiro: um terceiro enigmático. 2a ed. São Paulo: Saraiva, 2008.

CAPPELLETTI, Mauro, GARTH, Bryant. Acesso à Justiça. Tradução de Ellen Gracie Northfleet. Porto Alegre: Ed. Sérgio Antonio Fabris, 1988.

DAL BOSCO, Maria Goretti. Audiência pública como direito de participação. Revista dos Tribunais, 2002.

MACIEL, Adhemar Ferreia. Amicus curiae: um instituto democrático. ID/496885, 2001

MEDINA, Damares. Amigo da Corte ou amigo da parte? - amicus curiae no Supremo Tribunal Federal. São Paulo: Saraiva, 2008.

SILVA, José Afonso da. Curso de Direito Constitucional Positivo. 25ª ed. São Paulo: Malheiros, 2005.

SIMÕES, Carlos. Curso de Direito do Serviço Social. 7a ed. Revista e atualizada. São Paulo: Cortez, 2014.

SOARES, Evanna. Audiência pública no processo administrativo. Revista de direito administrativo, v. 229, p. 259-284, 2002.

VILHENA VIEIRA, Oscar. Supremocracia. Revista Direito GV, v. 4, n. 2.

Trabalho enviado em 09 de março de 2018

Aceito em 10 de junho de 2018 